\title{
Metabotropic Glutamate 2 Receptors Modulate Synaptic Inputs and Calcium Signals in Striatal Cholinergic Interneurons
}

\author{
Antonio Pisani, ${ }^{1,2}$ Paola Bonsi, ${ }^{1,2}$ Maria Vincenza Catania, ${ }^{3}$ Raffaella Giuffrida, ${ }^{4}$ Michele Morari, ${ }^{5}$ \\ Matteo Marti, ${ }^{5}$ Diego Centonze, ${ }^{1,2}$ Giorgio Bernardi, ${ }^{1,2}$ Ann E. Kingston, ${ }^{6}$ and Paolo Calabresi ${ }^{1,2}$ \\ ${ }^{1}$ Clinica Neurologica, Dipartimento di Neuroscienze, Università di Roma "Tor Vergata," 00133 Rome, Italy, ${ }^{2} F o n d a z i o n e$ \\ Santa Lucia, Istituto di Ricovero e Cura a Carattere Scientifico, 00179 Rome, Italy, ${ }^{3} /$ stituto di Scienze Neurologiche, \\ Consiglio Nazionale Ricerche, Sezione di Catania, 95123 Catania, Italy, ${ }^{4}$ Dipartimento di Scienze Chimiche, Sezione di \\ Biochimica, Università di Catania, 95125 Catania, Italy, ${ }^{5}$ Dipartimento di Farmacologia, Università di Ferrara, 44100 \\ Ferrara, Italy, and 'Lilly Research Laboratories, Eli Lilly and Company, Indianapolis, Indiana 46410
}

Striatal cholinergic interneurons were recorded from a rat slice preparation. Synaptic potentials evoked by intrastriatal stimulation revealed three distinct components: a glutamatergic EPSP, a $\mathrm{GABA}_{\mathrm{A}}$-mediated depolarizing potential, and an acetylcholine (ACh)-mediated IPSP. The responses to group II metabotropic glutamate (mGlu) receptor activation were investigated on the isolated components of the synaptic potentials. Each pharmacologically isolated component was reversibly reduced by bath-applied LY379268 and $\left(\left(2 S, 1^{\prime} R, 2^{\prime} R, 3^{\prime} R\right)-2-(2,3-\right.$ dicarboxylcyclopropyl)-glycine, group II agonists. In an attempt to define the relevance of group II mGlu receptor activation on cholinergic transmission, we focused on the inhibitory effect on the IPSP, which was mimicked and occluded by $\omega$-agatoxin IVA ( $\omega$-Aga-IVA), suggesting a modulation on P-type high-voltageactivated calcium channels. Spontaneous calcium-dependent plateau-potentials (PPs) were recorded with cesium-filled electrodes plus tetraethylammonium and TTX in the perfusing solution, and measurements of intracellular calcium $\left[\mathrm{Ca}^{2+}\right]_{i}$ changes were obtained simultaneously. PPs and the concom-

Striatal cholinergic transmission plays a fundamental role in the control of motor function, and the imbalance between striatal dopamine and acetylcholine (ACh) content has long been considered the neurochemical basis for movement abnormalities observed in Parkinson's disease (PD) (Barbeau, 1962; Lehmann and Langer, 1983; Hornykiewicz and Kish, 1987). Cholinergic innervation in the striatum is provided by a limited number of interneurons that supply this area with one of the highest content of ACh in the whole brain (Lehmann and Langer, 1983; Graybiel, 1990; Contant et al., 1996) and has been shown to play a key role in motor function. In vivo and in vitro intracellular recordings have shown that intrinsic membrane properties regulate the spontaneous activity of cholinergic interneurons and that synaptic inputs are capable of modulating the timing of this activity

\footnotetext{
Received Feb. 14, 2002; revised April 22, 2002; accepted April 22, 2002.

This work was supported by grants from Ministero dell'Università e della Ricerca Scientifica e Tecnologica (Cofin 2000) and Ministero Sanità (Progetto Alzheimer) (G.B. and A.P.) and Telethon Grant E.0930 (A.P.). We thank Prof. Anne B. Young for allowing us to analyze data from experiments performed in her laboratory, $\mathrm{M}$. Tolu for his technical support, and G. Bonelli for artwork.

Correspondence should be addressed to Antonio Pisani, Clinica Neurologica, Dipartimento di Neuroscienze, Università di Roma "Tor Vergata," Via di Tor Vergata 135, 00133 Rome, Italy. E-mail: pisani@uniroma2.it.

Copyright (C) 2002 Society for Neuroscience $0270-6474 / 02 / 226176-10 \$ 15.00 / 0$
}

itant $\left[\mathrm{Ca}^{2+}\right]_{i}$ elevations were significantly reduced in amplitude and duration by LY379268. The mGlu-mediated inhibitory effect on PPs was mimicked by $\omega$-Aga-IVA, suggesting an involvement of P-type channels. Moreover, electrically induced ACh release from striatal slices was reduced by mGlu2 receptor agonists and occluded by $\omega$-Aga-IVA in a dose-dependent manner. Finally, double-labeling experiments combining mGlu2 receptor in situ hybridization and choline acetyltransferase immunocytochemistry revealed a strong mGlu2 receptor labeling on cholinergic interneurons, whereas single-label isotopic in situ hybridization for mGlu3 receptors did not show any labeling in these large striatal interneurons. These results suggest that the mGlu2 receptor-mediated modulatory action on cell excitability would tune striatal ACh release, representing an interesting target for pharmacological intervention in basal ganglia disorders.

Key words: striatum; slices; metabotropic glutamate receptor; acetylcholine; calcium; TANs
(Wilson et al., 1990; Bennett and Wilson, 1998, 1999; Bennett et al., 2000).

Experimental evidence indicates that metabotropic glutamate (mGlu) receptors play a major role in governing the excitability of neurons in different brain areas, including the basal ganglia (Conn and Pin, 1997; Calabresi et al., 1999; Awad et al., 2000; Pisani et al., 2001). The modulation of synaptic integration on striatal cholinergic interneurons has been shown to exert a strong and direct influence on basal ganglia output structures (Calabresi et al., 2000; Kaneko et al., 2000; Raz et al., 2001). mGlu receptors are a heterogeneous family of eight G-protein-coupled receptors, cloned and divided into three groups differing in amino acid sequence, pharmacological properties, and second messengers to which they are linked. Group I includes mGlu1 and mGlu5, positively coupled to the phosphoinositide hydrolysis transduction pathway, whereas both group II (mGlu2 and mGlu3) and group III (mGlu4, mGlu6, mGlu7, and mGlu8) are negatively linked to cAMP levels (Conn and Pin, 1997).

The presence of mGlu receptors in the striatum has been documented extensively, and the expression patterns of the three groups revealed an heterogeneous distribution (Testa et al., 1994, 1995, 1998, Tallaksen-Greene et al., 1998). Immunohistochemical and pharmacological data have demonstrated recently the coex- 
istence, on cholinergic interneurons, of both group I mGlu1 and mGlu5 receptors, whose activation results in a significant increase in cell excitability (Tallaksen-Greene et al., 1998; Pisani et al., 2001). Immunoreactivity for mGlu $2 / 3$ in the striatum revealed a colocalization with synaptic vesicle protein 2 , a protein commonly associated with presynaptic terminals, indicating the presence of group II mGlu receptors on corticostriatal terminals (Testa et al., 1998). Accordingly, electrophysiological studies have shown a dose-dependent depression of the corticostriatal glutamatergic synaptic potentials by group II agonists recorded from both medium spiny neurons and cholinergic interneurons (Lovinger and McCool, 1995; Calabresi et al., 1999).

We used a combination of electrophysiological, optical, biochemical, and immunohistochemical approaches to evaluate the capability of group II mGlu receptor agonists to affect both intrinsic membrane properties and synaptic activity of cholinergic interneurons and to modulate striatal ACh release.

\section{MATERIALS AND METHODS}

Preparation and maintenance of the corticostriatal slices. Male Wistar rats (20-30 postnatal days) were used for the experiments. Preparation and maintenance of the slices have been described in detail previously $(\mathrm{Ca}-$ labresi et al., 1998, 1999; Pisani et al., 2000, 2001). In brief, animals were killed under ether anesthesia by cervical dislocation, the brain was quickly removed, and corticostriatal coronal slices (180- to $200-\mu \mathrm{m}$-thick) were cut from tissue blocks with the use of a vibratome in an ice-cold $\left(0^{\circ} \mathrm{C}\right) \mathrm{Krebs}$ 'solution (see composition below). A single slice was transferred into a recording chamber mounted on the stage of an upright microscope (Axioskop FS; Zeiss, Oberkochen, Germany), equipped with a $60 \times, 0.90$ numerical aperture water immersion objective (LUMPlan FI; Olympus Optical, Tokyo, Japan) and fully submerged in a continuously flowing Krebs' solution $\left(33^{\circ} \mathrm{C}, 3 \mathrm{ml} / \mathrm{min}\right)$ gassed with $95 \% \mathrm{O}_{2}-5 \% \mathrm{CO}_{2}$. The composition of the solution was (in $\mathrm{mM}$ ): $126 \mathrm{NaCl}, 2.5 \mathrm{KCl}, 1.3$ $\mathrm{MgCl}_{2}, 1.2 \mathrm{NaH}_{2} \mathrm{PO}_{4}, 2.4 \mathrm{CaCl}_{2}, 10$ glucose, and $18 \mathrm{NaHCO}_{3}$.

Optical setup. Cholinergic interneurons were impaled under visual guidance, according to their characteristic shape and size, up to $100 \mu \mathrm{m}$ beneath the surface of the slice. Individual neurons were visualized in situ using a differential interference contrast (DIC) (Nomarski optics) optical system combined with an infrared (IR) filter, a monochrome CCD camera (C3077; Hamamatsu, Shizouka, Japan), and an 11 inch monitor (Sony, Tokyo, Japan). A mechanical switch allowed to shift from IR-DIC to UV for microfluorometric measurements. For simultaneous optical and electrical recordings, the tip of the recording electrodes was filled with a solution of $1 \mathrm{~mm}$ bis-fura-2 (hexapotassium salt; Molecular Probes, Leiden, The Netherlands) and $100 \mathrm{~mm} \mathrm{KCl}$, whereas the shank was filled with a $2 \mathrm{M} \mathrm{KCl}$ solution or with an equimolar $\mathrm{CsCl}$ solution. After cell impalement, cells were loaded with bis-fura-2 by injecting, through the recording electrode, $0.1-0.5 \mathrm{nA}$ negative current for 10-15 min. Epi-illumination was provided by a $75 \mathrm{~W}$ xenon lamp. Excitation light passed through a shutter and excitation filters $(340$ and $380 \mathrm{~nm}$ ). Emitted light was filtered by a long-pass barrier filter $(>470 \mathrm{~nm})$ and detected by a CCD camera (Photonic Science, Robertsbridge, UK). Images were stored and analyzed offline (IonVision; ImproVision, Coventry, UK). Changes in $\left[\mathrm{Ca}^{2+}\right]_{\mathrm{i}}$ are expressed as $\Delta F / F_{0}$, where $\Delta F$ is the normalized fluorescence changes over time, and $F_{0}$ is the backgroundsubtracted basal fluorescence. The background fluorescence was measured in a part of the slice remote from bis-fura-2-filled neurons. The $\Delta F / F_{0}$ values can be interpreted as changes in $\left[\mathrm{Ca}^{2+}\right]_{\mathrm{i}}$ (Lev-Ram et al., 1992; Bennett et al., 2000).

Electrophysiological recordings. An Axoclamp 2A amplifier (Axon Instruments, Foster City, CA) was used for current-clamp recordings. For synaptic stimulation, bipolar electrodes were located within the striatum. Synaptic potentials were measured by averaging responses to four or eight stimuli, and samples were digitally stored. In a subset of experiments, to evoke calcium-mediated plateau potentials (PPs), electrodes were filled with $\mathrm{CsCl}(2 \mathrm{M})$, and, in the bathing solution, both tetrodotoxin (TTX) $(1 \mu \mathrm{M})$ and tetraethylammonium (TEA) (10 mM) were added (Misgeld et al., 1986). In this experimental condition, to balance TEA-induced changes in osmolarity, the concentration of $\mathrm{NaCl}$ was reduced to $120 \mathrm{~mm}$. Traces were displayed on an oscilloscope (Gould Classic 6000; Gould Instruments, Valley View, OH), stored on both a high-gain chart recorder (Gould RS 3400; Gould Instruments) and AxoScope 7.0 (Axon Instruments) running on a personal computer for offline analysis, performed with pClamp 8 (Clampfit). Both frequency and duration values are expressed as percentage of control, considered as $100 \%$. Drugs were applied by dissolving them to the desired final concentration in the saline and by switching the perfusion from control saline to drug-containing saline, after a three-way tap had been turned on. Values given in the text and in the figures are mean \pm SEM of changes in the respective cell populations. Student's $t$ test (for paired and unpaired observations) was used to compare the means.

mGlu2 in situ hybridization and ChAT immunocytochemistry. The cell type-specific expression of mGlu2 receptor subtype was studied in large aspiny interneurons of rat striatum by means of a double-labeling approach using a combination of nonradioactive in situ hybridization and immunocytochemistry.

Antisense cRNA synthesis. In situ hybridization was performed with an antisense cRNA for the mGlu2 receptor subtype. DNA template for the cRNA synthesis was prepared by subcloning a 500 fragment $($ Bam $\mathrm{H} 1-$ EcoRI) corresponding to the $3^{\prime}$ end of the mGlu2 coding sequence into the pBluescript $\mathrm{SK}^{-}$transcription vector (Stratagene, La Jolla, CA). The RNA synthesis was performed on linearized plasmids using a mixture of ATP (1 mM), CTP (1 mM), GTP (1 mM), UTP (0.65 mM), and digoxigenin (DIG)-11-UTP $(0.35 \mathrm{~mm})$ using the T7 (antisense) or T3 (sense) polymerase.

Tissue preparation. Animals were anesthetized and then quickly perfused through the ascending aorta with sodium phosphate $(50 \mathrm{~mm})$ buffer, $\mathrm{pH} 7.5$, containing $0.9 \% \mathrm{NaCl}$, followed by at least $300 \mathrm{ml}$ of freshly made fixative solution containing $4 \%$ paraformaldehyde in $10 \mathrm{~mm}$ PBS $(1 \times$ PBS). Brains were removed, postfixed overnight in the same fixative solution, and stored in a sterile cryoprotective solution of $20 \%$ sucrose in $100 \mathrm{~mm}$ sodium phosphate buffer at $4^{\circ} \mathrm{C}$ until use. Sections ( 40 $\mu \mathrm{m})$ were cut on a cryostat, collected in $1 \times$ PBS, and immediately processed for in situ hybridization. The nonradioactive in situ hybridization method used in the present project has been described in detail previously (Catania et al., 1995, 1998). After a prehybridization consisting of sequential steps in $0.2 \mathrm{M} \mathrm{HCl}, 0.25 \%$ acetic anhydride in $1.5 \%$ triethanolamine $-0.3 \mathrm{M} \mathrm{NaCl}, \mathrm{pH} 8$, and $0.1 \%$ Triton $\mathrm{X}-100$ in PBS, each followed by a brief rinse in $1 \times$ PBS, the free-floating sections were transferred into hybridization solution for $1 \mathrm{hr}$ at $55^{\circ} \mathrm{C}$. The hybridization solution consisted of a mixture of $50 \%$ formamide, $250 \mathrm{mg} / \mathrm{ml}$ heat denatured and sheared salmon sperm DNA, $0.05 \mathrm{~m}$ sodium phosphate buffer, $\mathrm{pH} 6.5,4 \times \mathrm{SSC}(1 \times \mathrm{SSC}, 150 \mathrm{~mm} \mathrm{NaCl}$, and $15 \mathrm{~mm}$ Na citrate, $\mathrm{pH} 7.0), 5 \%$ dextran sulfate, and $1 \times$ Denhart's solution. Sections were then incubated for at least $12 \mathrm{hr}$ at $55^{\circ} \mathrm{C}$ in the same solution with sense or antisense cRNA probes at a final concentration of $1 \mathrm{ng} / \mu \mathrm{l}$. After 10-20 min rinse in $4 \times \mathrm{SSC}$ at room temperature (RT), sections were treated with ribonuclease A $(50 \mu \mathrm{g} / \mathrm{ml})$ for $20 \mathrm{~min}$ at $37^{\circ} \mathrm{C}$. This was followed by rinsing in $2 \times \mathrm{SSC}$ for $2 \mathrm{hr}$ at RT and $0.1 \times \mathrm{SSC}$ for $30 \mathrm{~min}$ at $55^{\circ} \mathrm{C}$. Sections were rinsed again in $100 \mathrm{~mm}$ Tris- $\mathrm{HCl}$ buffer and 150 $\mathrm{mm} \mathrm{NaCl}$, pH 7.5 (buffer 1), preincubated for $1 \mathrm{hr}$ in the same buffer containing $4 \%$ BSA and $1 \%$ Triton X-100, and incubated overnight at $4^{\circ} \mathrm{C}$ in the alkaline phosphatase (AP)-conjugated antibodies (FAB fragment; Boehringer Mannheim, Mannheim, Germany) at 1:1000 dilution. On the following day, the sections were washed in buffer 1 (three times, $15 \mathrm{~min}$ each), rinsed twice ( $5 \mathrm{~min}$ each), and then incubated in buffer 2 [100 mM Tris- $\mathrm{HCl}, 100 \mathrm{~mm} \mathrm{NaCl}$, and $50 \mathrm{~mm} \mathrm{MgCl}_{2}, \mathrm{pH} 9.5$, containing $4.5 \mu \mathrm{l} / \mathrm{ml}$ nitroblue tetrazolium and $3.5 \mu \mathrm{l} / \mathrm{ml} \mathrm{X}$-phosphate stock solutions (Boehringer Mannheim, Mannheim, Germany)]. The chromogen reaction was stopped by rinsing the sections in $10 \mathrm{~mm}$ Tris- $\mathrm{HCl}$ and $1 \mathrm{~mm}$ EDTA, pH 8, for $15 \mathrm{~min}$ and in $10 \mathrm{~mm}$ Tris-HCl, pH 8, (twice, $15 \mathrm{~min}$ ). Sections were then processed for immunohistochemistry. mGlu2 receptor in situ hybridization signal appeared to be highly specific, as demonstrated by comparing the pattern of distribution with that obtained with ${ }^{35}$ S-labeled oligonucleotide (Catania et al., 1994; Testa et al., 1994). In addition, sections incubated with both sense DIG-labeled cRNA or antisense DIG-labeled cRNA in the presence of a 50-fold excess of nonlabeled cRNA did not show any signal.

Immunocytochemistry. After the AP reaction was stopped, sections were transferred into $50 \mathrm{~mm}$ Tris- $\mathrm{HCl}$ buffer containing $1.5 \% \mathrm{NaCl}, \mathrm{pH}$ 7.4 (TBS), and then permeabilized for $30 \mathrm{~min}$ in TBS with $0.4 \%$ Triton $\mathrm{X}-100$. This was followed by preincubation in TBS containing $4 \%$ donkey serum (DS). Sections were subsequently incubated overnight at $4^{\circ} \mathrm{C}$ in primary goat anti-ChAT antibody (1:100; Chemicon, Temecula, CA) in TBS containing $0.1 \%$ Triton X-100 and $2 \%$ DS. On the following day, sections were washed in cold TBS and incubated for $2.5 \mathrm{hr}$ in donkey 
anti-goat IgG Cy3-conjugated antibodies (1:200), at RT, in the dark (Jackson ImmunoResearch, West Grove, PA). Sections were then washed in TBS containing 1\% DS twice and in TBS alone twice (10 min each). After a brief final rinse in $10 \mathrm{~mm}$ Tris- $\mathrm{HCl}, \mathrm{pH}$ 7.5, sections were mounted on slides and coverslipped in mounting medium (Sigma, St. Louis, MO).

$m$ Glu3 in situ hybridization. Single-label isotopic in situ hybridization was performed as indicated previously (Catania et al., 1994). Specificity of the hybridization was tested previously by adding a 25 -fold excess of unlabeled probe to the hybridization solution (Catania et al., 1994; Testa et al., 1994). The general distribution of mGlu3 receptor mRNA has been detailed previously (Testa et al., 1994). Here, we performed a quantitative analysis of cellular mGlu3 expression (grain counting), and measurement of cell area in the striatum was performed on six dipped emulsion slides from adult animals, by using a computer-assisted quantitative image analysis system (Imaging Research, St. Catharine's, Ontario, Canada).

Measurement of endogenous acetylcholine. Striatal slices were set up in superfusion chambers $\left(1 \mathrm{~cm}^{2}\right.$ section, $3 \mathrm{~mm}$ depth, and $0.3 \mathrm{ml}$ volume), inserted in a thermostatic water bath at $37^{\circ} \mathrm{C}$, and equipped with stimulating platinum electrodes (Beani et al., 1978). The slices were superfused with oxygenated Krebs' solution (see composition above) containing eserine $(10 \mu \mathrm{M})$ and atropine $(10 \mathrm{nM})$ at a flow rate of $0.4 \mathrm{ml} / \mathrm{min}$ by means of a peristaltic pump (Minipulse; Gilson, Villiers Le Bel, France). Sample collection (every $3 \mathrm{~min}$ ) was started after a washout period of 30 min. The slices were subjected to a double cycle of electrical field stimulation applied for $2 \mathrm{~min}$ at the 39th and 60th minutes with the following parameters: intensity, $40 \mathrm{~mA} / \mathrm{cm}^{2}$; frequency, $1 \mathrm{~Hz}$; duration, $1 \mathrm{msec}$. These parameters were chosen based on previous studies from our group demonstrating exocitotic, calcium-dependent ACh release under these experimental conditions (Moroni et al., 1981). Moreover, because the amount of $\mathrm{ACh}$ released during the two stimulation cycles (named $\mathrm{St}_{1}$ and $\left.\mathrm{St}_{2}\right)$ is almost identical $\left(\mathrm{St}_{2} / \mathrm{St}_{1}\right.$ ratio, $1.03 \pm 0.02 ; n=35$ ), to test drug effect on neurosecretion, agonists were added to the Krebs' solution 6 min before and during $\mathrm{St}_{2}$ (when used antagonists were added 3 min before agonists), and changes of the $\mathrm{St}_{2} / \mathrm{St}_{1}$ ratio were evaluated. As described previously (Morari et al., 1998), endogenous ACh levels in the samples were measured by HPLC technique coupled to electrochemical detection according to the methods of Damsma et al. (1987). Briefly, a cation exchange column was prepared by loading reverse-phase analytical column (internal diameter of $3 \mathrm{~mm}$, length of $10 \mathrm{~cm}$; Chrompack, Middelburg, The Netherlands) with sodium lauryl sulfate $(5 \mathrm{mg} / \mathrm{ml})$ and perfused at a flow rate of $0.7 \mathrm{ml} / \mathrm{min}$ with a $0.2 \mathrm{M}$ phosphate buffer containing $5 \mathrm{~mm} \mathrm{KCl}, 1 \mathrm{~mm}$ tetramethylammonium, and $0.3 \mathrm{~mm}$ EDTA, $\mathrm{pH}$ 8. ACh was hydrolyzed by acetylcholinesterase and oxidized by choline oxidase in a postcolumn enzyme reactor, and hydrogen peroxide was maximally oxidized at $+500 \mathrm{mV}$. The electrochemical detector (BAS LC-4B; Bioanalytical Systems, West Lafayette, IN) was equipped with a platinum working electrode and an in situ $\mathrm{Ag} / \mathrm{AgCl}$ reference electrode. The limit of detection was $\sim 3 \mathrm{~nm}$. Statistical analysis was performed by the Kruskal-Wallis test for the nonparametric ANOVA, followed by the Mann-Whitney $U$ test (including the Bonferroni's correction) for multiple comparisons.

Drug source and handling. $(5 S, 10 R)-(+)-5$-Methyl-10,11-dihydro-5Hdibenzo [a,d] cyclohepten-5,10-imine maleate (MK-801), CNQX,

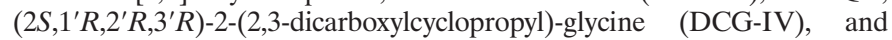
LY341495 were from Tocris Cookson (Bristol, UK); nifedipine, $\omega$-conotoxin GVIA ( $\omega$-Ctx-GVIA), $\omega$-conotoxin-MVIIC $(\omega$-CtxMVIIC), and $\omega$-agatoxin IVA ( $\omega$-Aga-IVA) were from Alomone Labs (Jerusalem, Israel); scopolamine, bicuculline methiodide (BMI), TTX, and TEA were from Sigma (Milan, Italy). Eserine, acetylcholinesterase, and choline oxidase were purchased from Sigma (St. Louis, MO). LY379268 was a gift from Eli Lilly and Company.

\section{RESULTS}

\section{Characterization of cholinergic interneurons}

Electrophysiological data were collected from 164 striatal interneurons, recorded from a slice preparation. The large and polygonal shape of the cell body $(25-46 \mu \mathrm{m})$ and the two to four dendritic branches allowed the visual identification of these cells by means of IR-DIC videomicroscopy and by bis-fura-2fluorescence (Fig. 1A). These neurons displayed electrophysiological characteristics that have been attributed previously to
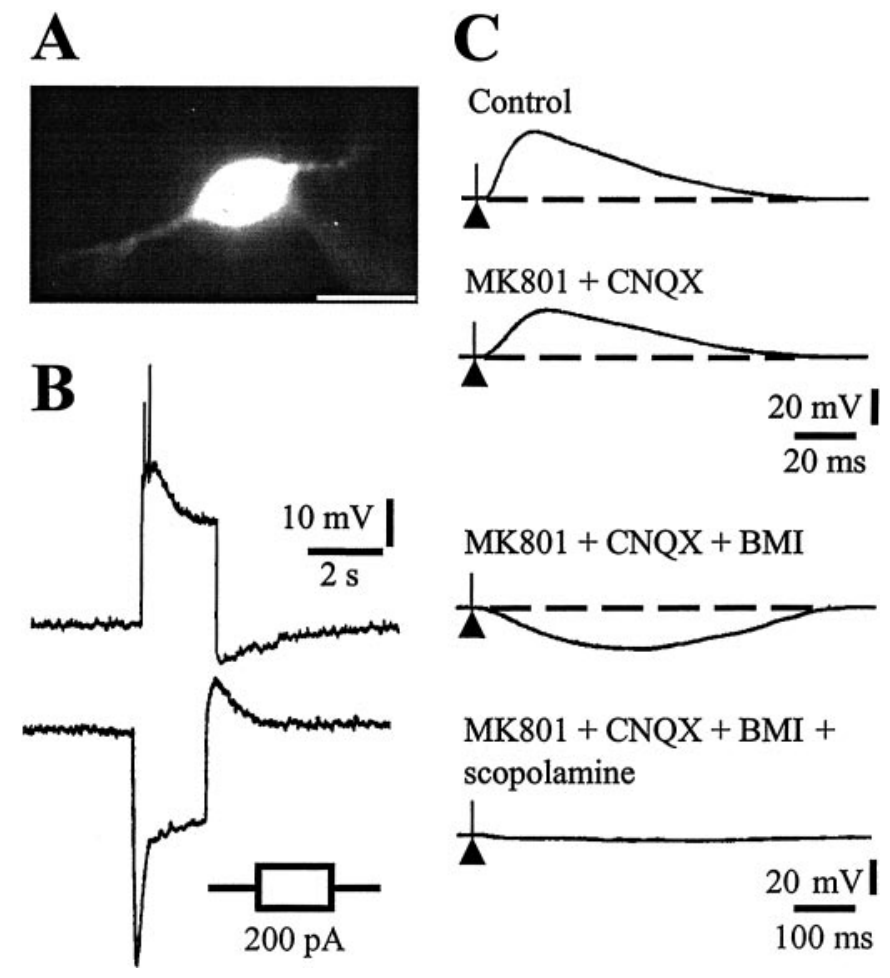

Figure 1. Distinctive features of striatal cholinergic interneurons. A, A $380 \mathrm{~nm}$ fluorescence image of a cholinergic interneuron recorded with a bis-fura-2-containing electrode (average of 256 images). Note the relatively large soma and two main dendritic branches. Scale bar, $25 \mu \mathrm{m}$. $B$, Depolarizing current pulses evoked a spike discharge, followed by a pronounced afterhyperpolarization; full action potential height was truncated. Note the "sag" conductance appearing during current pulses in the hyperpolarizing direction, expression of an $I_{\mathrm{h}}$ current. $C$, Intrastriatal synaptic stimulation evoked an EPSP that was fully blocked by the coadministration of ionotropic glutamate receptors $\mathrm{MK}-801(30 \mu \mathrm{M})$ and CNQX $(10 \mu \mathrm{M})$ plus BMI $(10 \mu \mathrm{M}), \mathrm{a} \mathrm{GABA}_{\mathrm{A}}$ receptor antagonist. In the presence of MK-801, CNQX and BMI synaptic stimulation revealed a slow, muscarinic IPSP, fully blocked by scopolamine $(1 \mu \mathrm{M})$.

striatal cholinergic interneurons (Kawaguchi, 1993; Kawaguchi et al., 1995; Aosaki et al., 1998; Pisani et al., 1999). Spontaneous firing occurred in nearly $50 \%$ of the cells. Low membrane potential $(-62 \pm 3.4 \mathrm{mV})$ and high input resistance $(145 \pm 56 \mathrm{M} \Omega)$ are typical features of these cells. Small depolarizing current pulses (100-500 pA) elicited few action potentials, followed by a longlasting afterhyperpolarization $(350 \pm 130 \mathrm{msec})$ (Fig. 1B). The amplitude of the action potential was $70.5 \pm 3 \mathrm{mV}$, and the duration of spike at half-amplitude was $0.71 \pm 0.05 \mathrm{msec}$. During hyperpolarizing current pulses $(100-400 \mathrm{pA}, 2-3 \mathrm{sec})$, a timedependent decline of the electrotonic potential could be observed, indicating the presence of an $I_{\mathrm{h}}$ (Fig. $1 B$ ).

Intrastriatal synaptic stimulation evoked EPSPs in the recorded cells (Fig. 1C). Because a spontaneous firing activity was observed in part of the cells, negative current (up to $100 \mathrm{pA}$ ) was injected through the recording electrode to hyperpolarize the cell and hold the membrane potential at approximately $-70 \mathrm{mV}$. Bath application of the NMDA glutamate receptor antagonist MK-801 $(30 \mu \mathrm{M})$ significantly reduced both the amplitude and the duration of the EPSP, and the subsequent addition of the AMPA glutamate receptor antagonist CNQX $(10 \mu \mathrm{M})$ further reduced the amplitude of these potentials to $\sim 30 \%$ of the control value (Fig. $1 C)$. The complete suppression of the residual depolarizing potential was obtained by adding $10 \mu \mathrm{M}$ BMI or $50 \mu \mathrm{M}$ picrotoxin, 
$\mathrm{GABA}_{\mathrm{A}}$ receptor antagonists (Fig. $1 C$ ). It should be noted that the depolarizing feature of the $\mathrm{GABA}_{\mathrm{A}}$ responses was attributable to the intracellular loading with $\mathrm{KCl}$. After full blockade of the glutamatergic and GABAergic components, the stimulus intensity was slightly increased, revealing a slow hyperpolarizing potential (IPSP) (Fig. $1 C$ ). This potential ranged from 3 to $12 \mathrm{mV}$ in amplitude and from 400 to $750 \mathrm{msec}$ in duration $(n=108)$. As described previously (Calabresi et al., 1998, Pisani et al., 2000), this IPSP results from an increase in membrane potassium conductance and is completely blocked by the muscarinic receptor antagonists scopolamine (1 $\mu \mathrm{M})$ (Fig. $1 C)$.

\section{Effect of group II and III mGlu receptor activation on cholinergic IPSP}

In the presence of a combination of ionotropic glutamate receptor and $\mathrm{GABA}_{\mathrm{A}}$ receptor blockers, brief bath application of the selective group II mGlu receptor agonist LY379268 (1-30 $\mu \mathrm{M})$ did not, per se, affect resting membrane potential, action potential amplitude, and input resistance of the recorded neurons but was able to reversibly reduce the amplitude of this IPSP in a dosedependent manner $(n=38$; $p<0.005)$ (Fig. $2 A, B)$. A doseresponse curve analysis revealed an $\mathrm{IC}_{50}$ value of $1.6 \pm 0.5 \mu \mathrm{M}$. Similarly, DCG-IV significantly reduced the IPSP amplitude (1 $\mu \mathrm{M} ; 40 \pm 8 \% ; n=7 ; p<0.01$; data not shown). The inhibitory effect produced by both agonists was prevented by perfusing the slices with LY341495 (3 $\mu \mathrm{M})$, a selective group II mGlu receptor antagonist (data not shown). It has been reported recently that multiple high-voltage-activated (HVA) calcium channels contribute to inhibitory synaptic transmission onto cholinergic interneurons. In particular, it was reported that blockade of P/Q-type HVA channels abolishes nearly $80 \%$ of GABA $_{A}$-mediated synaptic currents (Momiyama and Koga, 2001). Interestingly, bathapplied $\omega$-Aga-IVA (20 nM), known to selectively block, at this concentration, P-type HVA calcium channels, was able to mimic the inhibitory action of LY379268 $(n=16 ; 57 \pm 6.6 \% ; p<0.01)$ (Fig. $2 C$ ). Indeed, in the presence of $\omega$-Aga-IVA, perfusion with $10 \mu \mathrm{M}$ LY379268 did not produce any additional decrease in IPSP amplitude (Fig. $2 C$ ), suggesting that $\omega$-Aga-IVA targeted the same element. Previous reports have demonstrated that activation of dopamine $\mathrm{D}_{2}$-like receptors by quinpirole significantly reduced the cholinergic IPSP and that this effect was occluded by the N-type channel blocker $\omega$-Ctx-GVIA (Pisani et al., 2000). Similarly, $\mathrm{GABA}_{\mathrm{A}}$-mediated synaptic input to cholinergic interneurons was reduced by quinpirole and mimicked by $\omega$-CtxGVIA (Momiyama and Koga, 2001). We therefore tested whether $\omega$-Ctx-GVIA could interfere with the mGlu2/ $\omega$-AgaIVA-mediated inhibitory action. As shown in Figure $2 D$, bathapplied $\omega$-Ctx-GVIA $(1 \mu \mathrm{M})$ reduced the IPSP amplitude $(n=9$; $65 \pm 6 \% ; p<0.005$ ) (Fig. 2D). Indeed, in the presence of $\omega$-Ctx-GVIA, LY379268 was still effective, producing an additional reduction in the amplitude of the synaptic potential.

Muscarine and oxotremorine, a muscarinic $\mathrm{M}_{2}$-like receptor agonist, have been shown to hyperpolarize cholinergic interneurons (Calabresi et al., 1998). The membrane hyperpolarization was coupled to decreased basal levels of intracellular calcium, presumably attributable to the reduced firing activity (Pisani et al., 1999). Because $\mathrm{M}_{2}$-like muscarine receptors and mGlu2 receptors share the same coupling to $G_{0}$ class proteins, we tested whether the oxotremorine-induced hyperpolarization was affected by LY379268. Figure $2 E$ shows that bath-applied oxotremorine (300 $\mathrm{nM}, 1 \mathrm{~min}$ ) reversibly hyperpolarized the recorded neuron, interrupting the spontaneous firing discharge

\section{in $\mathrm{MK801}+\mathrm{CNQX}+\mathrm{BMI}$}

A B

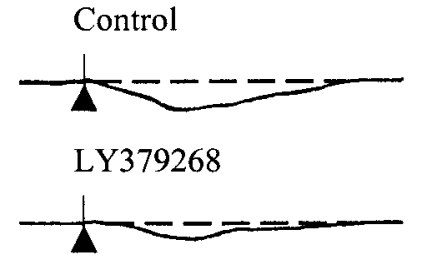

C

Control

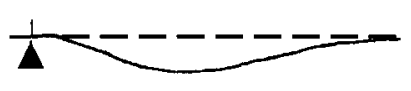

$\omega$-Aga-IVA

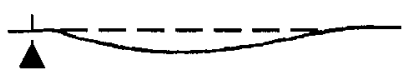

$\omega$-Aga-IVA + LY379268

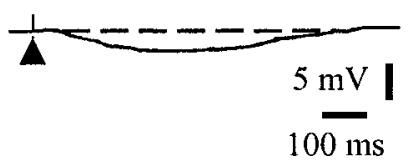

$\mathbf{E}$

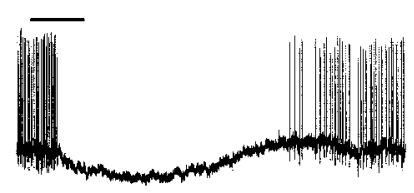

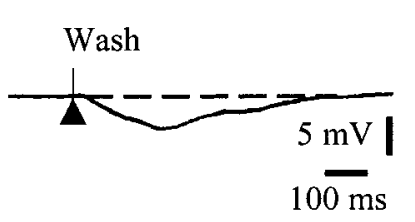

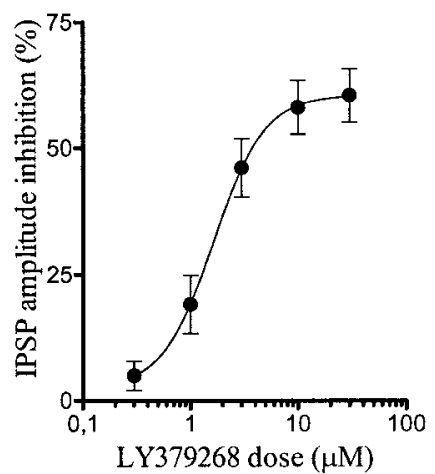

D

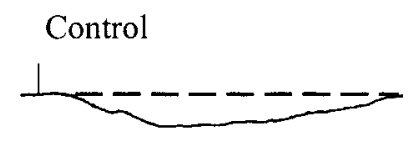

$\omega$-Ctx-GVIA

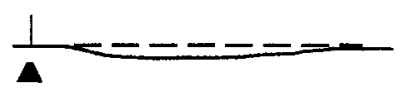

$\omega-$ Ctx-GVIA + LY379268

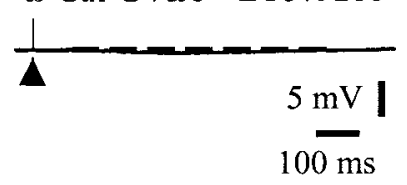

in LY379268

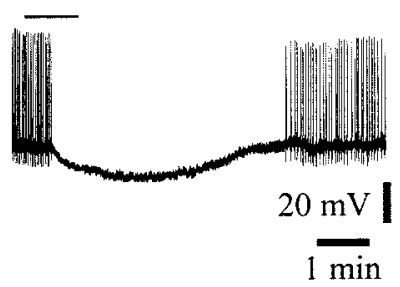

Figure 2. LY379268 exerts an inhibitory effect on IPSP recorded from cholinergic interneurons. $A$, A control IPSP evoked by intrastriatal stimulation in MK-801, CNQX, and BMI (30, 10, and $10 \mu \mathrm{M}$, respectively) in the perfusing solution was significantly reduced in amplitude by LY379268 (5 min, $10 \mu \mathrm{M})$ in a reversible manner. $B$, A dose-response curve for the inhibitory effect of LY379268 revealed an $\mathrm{IC}_{50}$ of $1.6 \pm 0.5$ $\mu \mathrm{M}$. Each data point was obtained by averaging at least four independent observations. $C$, The P-type HVA channel blocker $\omega$-Aga-IVA (20 nM) significantly reduced the IPSP amplitude recorded in $30 \mu \mathrm{M} \mathrm{MK}-801,10$ $\mu \mathrm{M}$ CNQX, and $10 \mu \mathrm{M}$ BMI. After reaching a steady-state inhibition with $\omega$-Aga-IVA, coapplication of $\omega$-Aga-IVA plus LY379268 (10 $\mu \mathrm{M})$ did not induce any further decrease in IPSP amplitude. $D, \omega$-Ctx-GVIA $(1 \mu \mathrm{M})$ reduced the IPSP amplitude. The following bath application of LY379268 $(10 \mu \mathrm{M})$ produced an additional decrease in the IPSP amplitude. $E$, Bath application of oxotremorine ( $300 \mathrm{nM}, 1 \mathrm{~min}$ ) hyperpolarized the recorded cell and blocked the action potential discharge in a reversible manner. In LY379268 $(10 \mu \mathrm{M}, 10 \mathrm{~min}$ preincubation), the oxotremorine-mediated effect was not modified. 
A in BMI + scopolamine

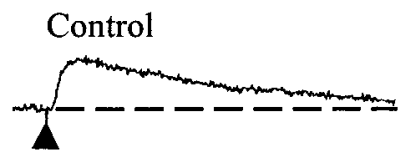

LY379268
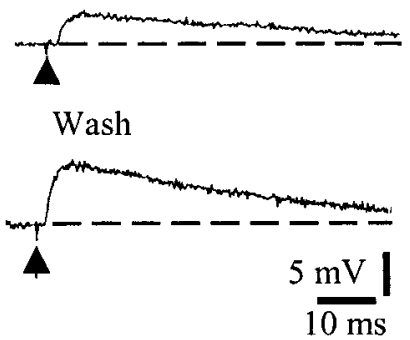

B

\section{in $\mathrm{MK801}+\mathrm{CNQX}$ + scopolamine}

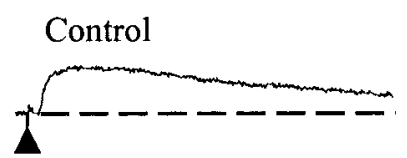

LY379268

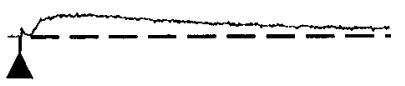

Wash

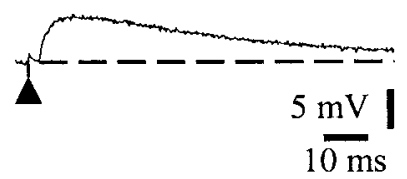

Figure 3. Glutamate- and GABA-mediated synaptic components are inhibited by group II mGlu receptor activation. $A$, The glutamatemediated component of the EPSP was isolated by bathing the slice in a solution containing BMI $(10 \mu \mathrm{M})$, a $\mathrm{GABA}_{\mathrm{A}}$ receptor antagonist, plus scopolamine $(1 \mu \mathrm{M})$. In this condition, LY379268 $(10 \mu \mathrm{M}, 5 \mathrm{~min})$ reduced the EPSP amplitude without affecting intrinsic membrane properties. A complete return to baseline values was observed 10-15 min after washout. $B$, In the presence of the ionotropic glutamate receptor antagonists MK-801 $(30 \mu \mathrm{M})$ and CNQX $(10 \mu \mathrm{M})$ plus scopolamine, the GABAergic component of the synaptic potential was significantly reduced by LY379268 (10 $\mu \mathrm{M}, 5 \mathrm{~min})$. This inhibitory effect was fully reversed after 10-15 min washout. Resting membrane potential was constant throughout the experiment $(-66$ and $-60 \mathrm{mV})$.

observed in control condition. However, in the presence of LY379268 $(10 \mu \mathrm{M})$ in the bathing solution, the oxotremorinemediated hyperpolarization was unaffected, suggesting that two independent mechanisms underlie their effects.

Neither L-AP-4 (10-30 $\mu \mathrm{M})$ nor L-serine- $O$-phosphate (SOP) $(10-30 \mu \mathrm{M})$ were able to significantly affect the IPSP amplitude, suggesting that group III does not contribute to modulate the ACh-mediated synaptic potential $(n=18 ; p>0.01$; data not shown).

\section{Modulation of glutamate- and GABA-mediated synaptic components by group II mGlu receptors}

Previously, it has been shown that glutamate-mediated EPSPs evoked by cortical stimulation are negatively modulated at presynaptic level by group II mGlu receptor agonists, presumably located on corticostriatal glutamatergic terminals (Lovinger and McCool, 1995; Calabresi et al., 1999). We analyzed the responses to group II mGlu receptor activation on the glutamatergic component of the EPSP evoked by intrastriatal synaptic stimulation. In the presence of BMI and scopolamine in the bathing solution, LY379268 $(10 \mu \mathrm{M})$ was able to reversibly depress the EPSP amplitude $(53 \pm 8 \% ; n=7 ; p<0.05)$ (Fig. 3A). Similarly, DCG-IV $(1 \mu \mathrm{M})$ reduced the glutamate-mediated EPSP (61 \pm $9 \% ; n=7 ; p<0.005$; data not shown). Continuous perfusion with CNQX $(10 \mu \mathrm{M}), \mathrm{MK}-801(30 \mu \mathrm{M})$, and scopolamine revealed a $\mathrm{GABA}_{\mathrm{A}}$-dependent, BMI-sensitive depolarizing potential (DPSP) (Fig. 2A). The selective group II agonists LY379268 (10 $\mu \mathrm{M} ; 58 \pm 6 \% ; n=16 ; p<0.001)$ (Fig. $3 B)$ and DCG-IV $(1 \mu \mathrm{M}$; $60 \pm 5 \% ; n=8 ; p<0.05$; data not shown) induced a dosedependent, reversible decrease in the amplitude of the DPSP, with no detectable change on action potential amplitude, resting membrane potential, and input resistance.

\section{Modulation of calcium-mediated plateau potentials}

A subset of experiments was performed by filling microelectrodes with $\mathrm{CsCl}$ and bis-fura-2. In this condition, and in the presence of TEA (10 mM) and TTX (1 $\mu \mathrm{M})$ in the external medium, a slow, spontaneous electrical activity was recorded $(0.25 \pm 0.02 \mathrm{~Hz})$, characterized by long-lasting $(575 \pm 80 \mathrm{msec})$ depolarizing PPs $(n=34)$ (Fig. 4) (Misgeld et al., 1986). The mean firing rates of cholinergic interneurons in vitro have been reported to be between 1 and $2 \mathrm{~Hz}$ (Bennett et al., 2000). In this particular experimental condition, it is conceivable to record significantly lower mean frequencies, especially considering the long duration of spontaneous PPs.

Combined microfluorometric measurements allowed a simultaneous analysis of the increases in $\left[\mathrm{Ca}^{2+}\right]_{\mathrm{i}}$ (Fig. $4 A$ ). A cocktail of HVA calcium channel blockers (Wheeler et al., 1994) composed of nifedipine $(10 \mu \mathrm{M})$ for L-type, $20 \mathrm{~nm} \omega$-Aga-IVA for P-type, $1 \mu \mathrm{M} \omega$-Ctx-GVIA for N-type, and $1 \mu \mathrm{M} \omega$-Ctx-MVIIC for Q-type fully blocked both the electrical events and the simultaneous $\left[\mathrm{Ca}^{2+}\right]_{\mathrm{i}}$ transients $(n=12)$ (Fig. $\left.4 B\right)$.

Bath-applied LY379268 (10 $\mu \mathrm{M}, 10 \mathrm{~min})$ was able to reversibly reduce the duration of PPs (52.9 $\pm 6 \%$ of control) (Figs. $5 A, 6 b)$, as well as the peak amplitude of coincident $\left[\mathrm{Ca}^{2+}\right]_{\mathrm{i}}$ transients $(n=16 ; 58 \pm 4.3 \%$ of control; $p<0.005)$ (Fig. $5 A)$. Analogous results were obtained with DCG-IV $(n=9 ; 1 \mu \mathrm{M} ; p<0.001$; data not shown). Because the cholinergic IPSP was significantly reduced in amplitude by $\omega$-Aga-IVA, we verified whether also the spontaneous PPs were affected by the P-type HVA blocker. The decrease in duration induced by LY379268 was mimicked and occluded by 20 nм $\omega$-Aga-IVA (data not shown; $n=10 ; 51.6 \pm$ $7.5 \%$ of control; $p<0.005$ ), supporting an involvement of P-type channels. Accordingly, peak amplitude of $\left[\mathrm{Ca}^{2+}\right]_{\mathrm{i}}$ transients was reduced by $\omega$-Aga-IVA $(n=11 ; 57 \pm 7.5 \%$ of control; $p<0.005)$ (Fig. 5B).

Quinpirole, a $\mathrm{D}_{2}$-like dopamine receptor agonist, was shown to modulate N-type channels (Yan et al., 1997; Momiyama and Koga, 2001). We therefore tested whether the inhibitory action on PPs exerted by LY379268 and occluded by $\omega$-Aga-IVA was affected by $\omega$-Ctx-GVIA. $\omega$-Aga-IVA $(20 \mathrm{~nm})(10 \mathrm{~min})$ reversibly reduced the duration of PPs compared with controls (Fig. 6a,b), as well as the peak amplitude of coincident $\left[\mathrm{Ca}^{2+}\right]_{\mathrm{i}}$ transients. In the presence of $\omega$-Aga-IVA, $\omega$-Ctx-GVIA $(1 \mu \mathrm{M})$ further decreased PPs duration. Accordingly, the simultaneous $\left[\mathrm{Ca}^{2+}\right]_{\mathrm{i}}$ elevation was further reduced $(n=6 ; 33 \pm 8 \%$ of control; $p<$ 0.001) (Fig. 6c).

\section{Endogenous $\mathrm{ACh}$ release and its modulation by group II $\mathrm{mGlu}$ receptor agonists}

A set of experiments was performed on a striatal slice preparation to measure endogenous ACh release and the possible modulatory role of group II mGlu receptor agonists. ACh released during the two stimulation cycles (named $\mathrm{St}_{1}$ and $\mathrm{St}_{2}$ ) is nearly identical $\left(\mathrm{St}_{2} / \mathrm{St}_{1}\right.$ ratio, $\left.1.03 \pm 0.02 ; n=35\right)$. Thus, to test drug effect on endogenous ACh secretion, agonists were added to the perfusing solution before and during $\mathrm{St}_{2}$, and changes of $\mathrm{St}_{2} / \mathrm{St}_{1}$ ratio were evaluated (for additional details, see Materials and Methods). Indeed, ACh release induced by electrical stimulation was significantly reduced by DCG-IV in a dose-dependent manner $(n=30$; $p<0.005)$ (Fig. 7A). LY379268 $(10 \mu \mathrm{M})$ caused a quantitatively similar decrease in ACh release that was mimicked and occluded 
A

$\mathbf{a}$
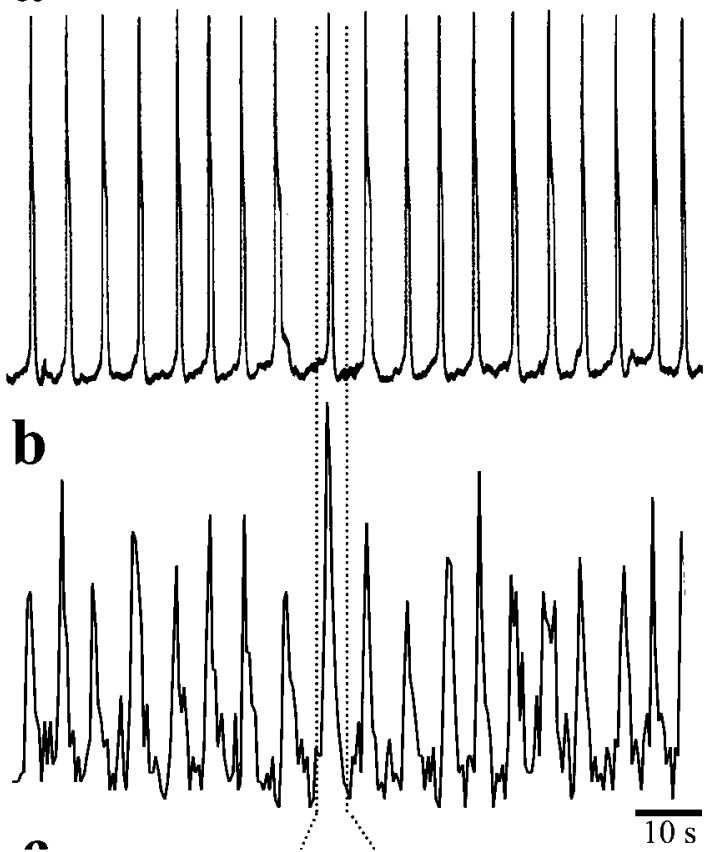

c

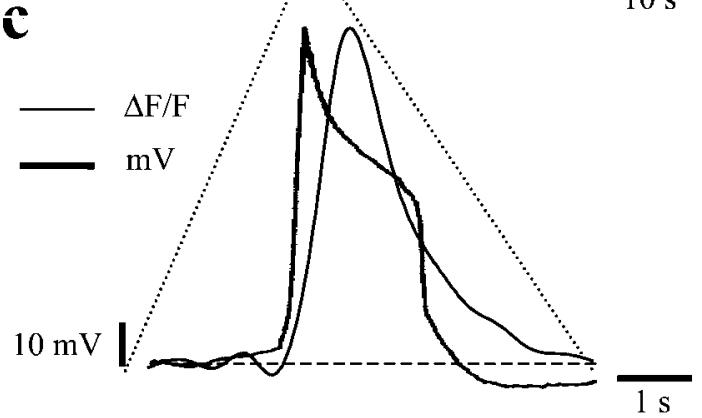

B

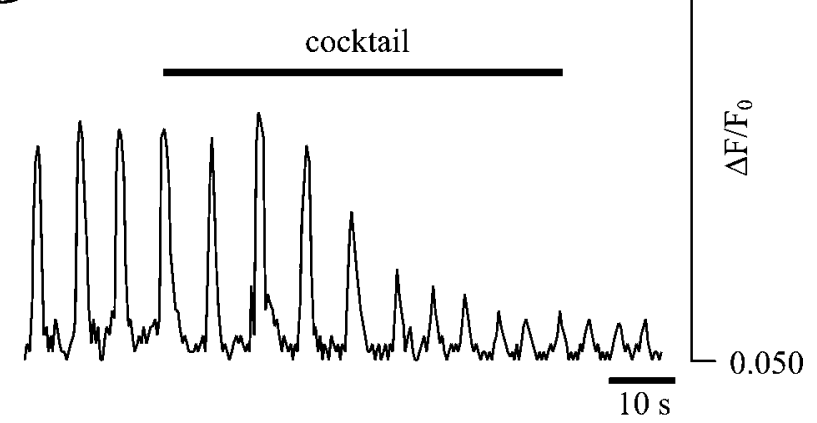

Figure 4. Spontaneous calcium-dependent PPs and simultaneous $\left[\mathrm{Ca}^{2+}\right]_{\mathrm{i}}$ transients. $A$, Intracellular recordings were performed with $1 \mu \mathrm{M}$ TTX and $10 \mathrm{~mm}$ TEA in the perfusing solution and $\mathrm{CsCl}(2 \mathrm{M})$ plus bis-fura-2 $(1 \mathrm{mM})$ in the recording microelectrode. In this experimental condition, a spontaneous, rhythmic spiking activity was generated $(a)$. Each of these long-lasting PPs was followed by a prominent afterhyperpolarization and was coupled to a simultaneous transient increase in $\left[\mathrm{Ca}^{2+}\right]_{\mathrm{i}}$, as revealed by combined optical recordings $(b)$. In $c$, at higher sweep speed (compare time scale in $A$ ), a single PP (thick bar) and the coincident $\left[\mathrm{Ca}^{2+}\right]_{\mathrm{i}}$ rise (thin bar) are shown. The dotted line indicates which PP was enlarged in $b . B,\left[\mathrm{Ca}^{2+}\right]_{\mathrm{i}}$ transients were fully blocked by perfusing a cocktail solution; HVA calcium channel blockers were composed of $10 \mu \mathrm{M}$ nifedipine for L-type, $20 \mathrm{nM} \omega$-Aga-IVA for P-type, $1 \mu \mathrm{M}$ $\omega$-conotoxin GVIA for N-type, and $1 \mu \mathrm{M} \omega$-conotoxin MVIIC for Q-type.

A

a Control LY379268 b
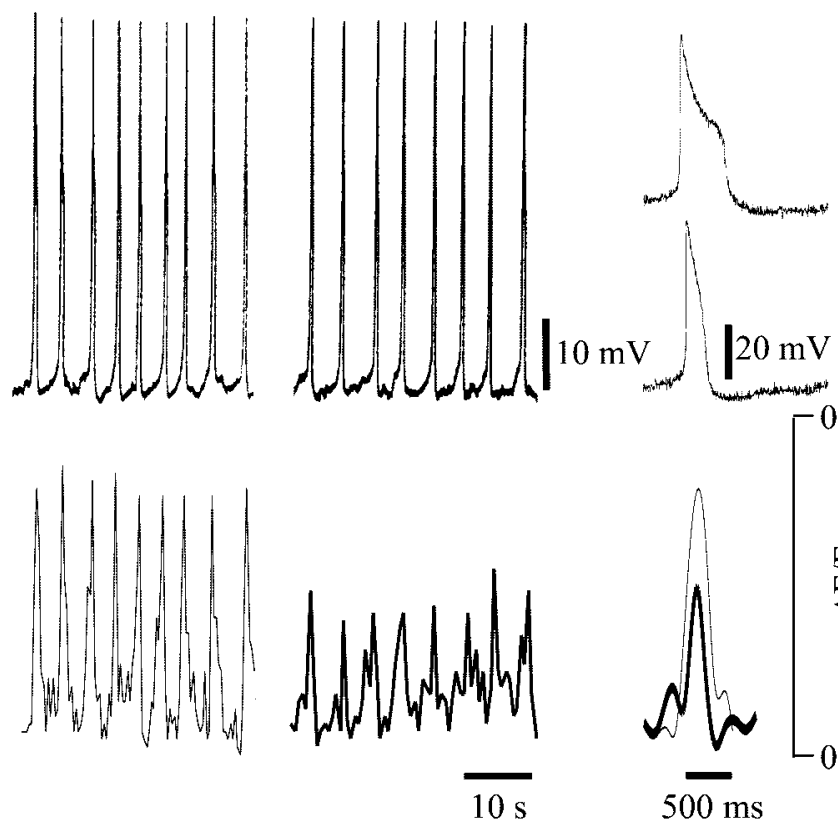

$\overline{10 \mathrm{~s}}$
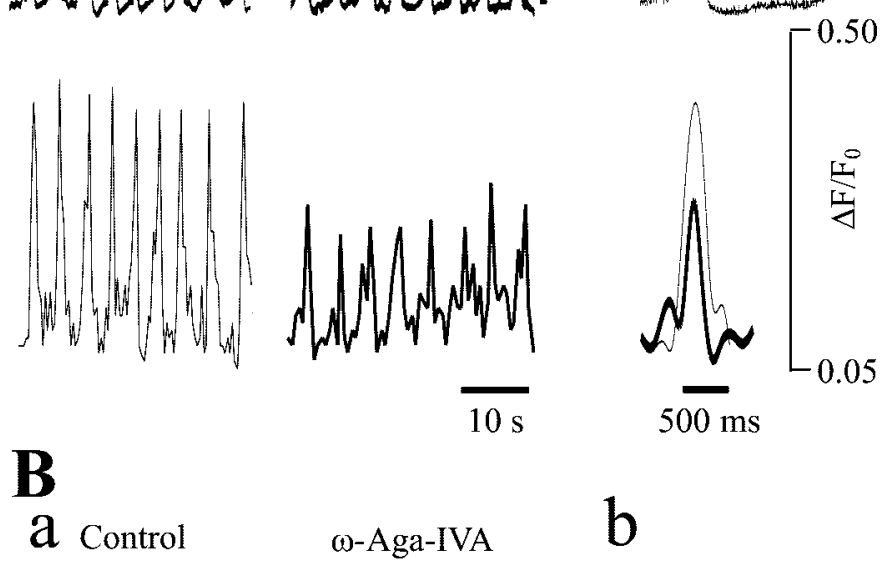

$\omega-$ Aga-IVA

$\mathrm{b}$
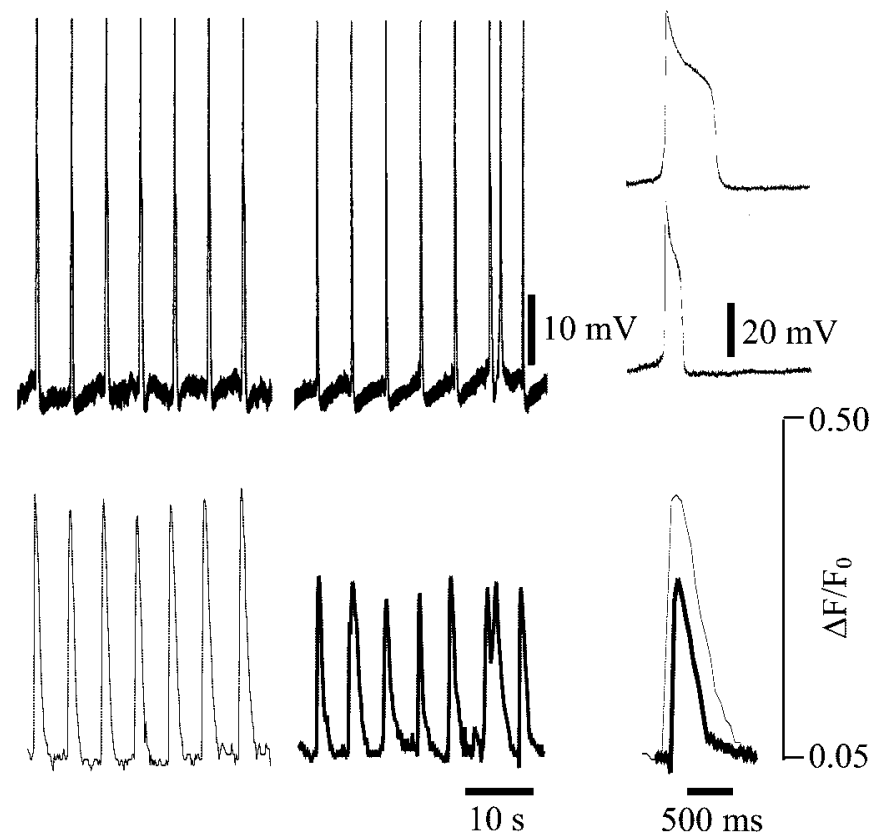

Figure 5. LY379268 reduces calcium-dependent PPs by modulating P-type calcium channels. $A a$, Spontaneous PPs recorded from a cholinergic interneuron (top) and simultaneous $\left[\mathrm{Ca}^{2+}\right]_{\mathrm{i}}$ elevation (bottom) in control condition and in the presence of LY379268 $(10 \mu \mathrm{M})$. At higher sweep speed, the trace represents a single PP in controls and in LY379268 (b). Note the net reduction caused by LY379268 both in PPs duration and increase in $\left[\mathrm{Ca}^{2+}\right]_{\mathrm{i}}(b) . \mathrm{Ba}$, Similarly, bath-applied $\omega$-Aga-IVA (20 nM) mimicked the inhibitory effect induced by the mGlu receptor agonist, on both the duration of PP and the concomitant $\left[\mathrm{Ca}^{2+}\right]_{\mathrm{i}}$ rise. The trace on the right $(b)$ shows, at higher sweep speed, the action of $\omega$-Aga-IVA on a single PP and on a individual $\left[\mathrm{Ca}^{2+}\right]_{\mathrm{i}}$ transient. 


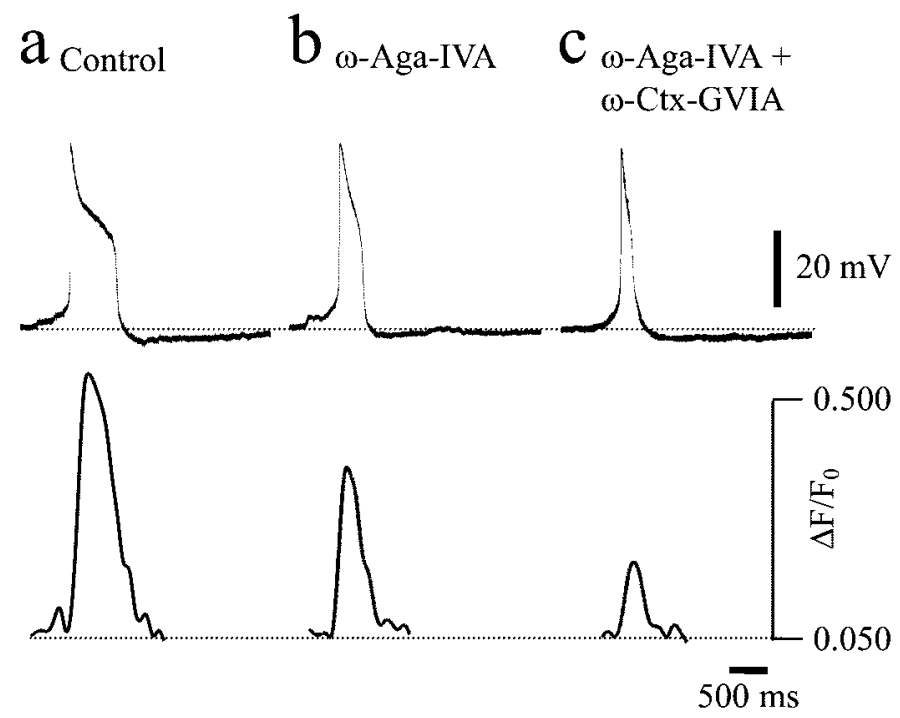

Figure 6. Additive effects of $\omega$-Aga-IVA and $\omega$-Ctx-GVIA on PPs. $\omega$-Aga-IVA $(20 \mathrm{nM}, 10 \mathrm{~min})$ reversibly reduced the duration of PPs compared with controls $(a, b)$, as well as the peak amplitude of coincident $\left[\mathrm{Ca}^{2+}\right]_{\mathrm{i}}$ transients. In $\omega$-Aga-IVA, $\omega$-Ctx-GVIA $(1 \mu \mathrm{M})$ produced an additional decrease in PPs duration, as well as in the simultaneous $\left[\mathrm{Ca}^{2+}\right]_{\mathrm{i}}$ elevation $(c)$.
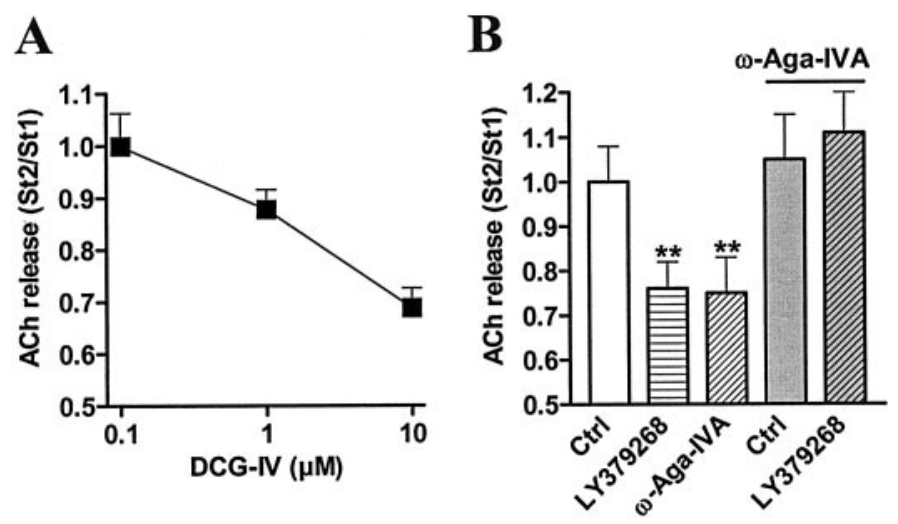

Figure 7. mGlu2 receptor activation reduces ACh release through the suppression of $\mathrm{P}$-type calcium channels. $A$, A dose-response curve for the inhibitory effect of the group II mGlu agonist DCG-IV on the electrically evoked release of endogenous ACh from a striatal slice preparation, expressed as the $\mathrm{St}_{2} / \mathrm{St}_{1}$ ratio values (electrical stimulation after and before agonist administration, respectively). Each data point was obtained from at least six independent observations. All experiments were performed in the presence of $30 \mu \mathrm{M}$ MK-801. $B$, Summary plots showing that the inhibitory action of LY379268 was mimicked and occluded by $\omega$-AgaIVA. In slices preincubated in $\omega$-Aga-IVA, LY379268 (ratio St2/St1) was no more effective in the modulation of ACh release compared with controls.

by $\omega$-Aga-IVA (20 nM, $n=6$ ) (Fig. $7 B$ ). In addition, in slices preincubated with $20 \mathrm{~nm} \omega$-Aga-IVA for $30 \mathrm{~min}$, LY379268 was unable to affect the stimulated ACh release (Fig. $7 B$ ), supporting the evidence of a complete mutual occlusion between the mGlu2 receptor agonist and $\omega$-Aga-IVA.

\section{mGlu2 receptor in situ hybridization and ChAT immunocytochemistry double-labeling analysis}

Nonradioactive in situ hybridization allowed a clear visualization of neurons labeled for mGlu2 receptor subtype. The general distribution of AP labeling was similar to the distribution of
mGlu2 subtype obtained with antisense ${ }^{35}$ S-oligonucleotides and was described previously (Testa et al., 1995). The signal was particularly strong in isolated cells of the internal granule cells layer, which might correspond to Golgi or Lugaro cells and the entorhinal cortex (data not shown). Signal was not present in astrocytes. The expression of mGlu2 in the striatum was low or undetectable in the vast majority of neurons. However, scattered large- and medium-sized neurons were moderately or strongly labeled. Double-labeling experiments using an anti-ChAT antibody revealed that the great majority of ChAT-positive neurons $(n=123 ; 95 \pm 1.1 \% ; p<0.001)$ (Fig. 8 ) were indeed mGlu2 mRNA positive. Few neurons labeled for mGlu2 mRNA were not immunopositive for ChAT. These neurons were smaller than cholinergic neurons and might represent another population of striatal interneurons.

\section{mGlu3 receptor in situ hybridization analysis}

The general distribution of mGlu3 mRNA signal was identical to that described by Testa et al. (1994). Briefly, the signal was moderate in the striatum, cortex, and the corpus callosum and was abundant in the thalamic reticular nucleus. The majority of neurons in the striatum appeared uniformly and moderately labeled, with the exception of few large polygonal cells. Quantitative analysis of grain counting confirmed that cells with an area larger than $300 \mu \mathrm{m}^{2}\left(365 \pm 59 \mu \mathrm{m}^{2} ; n=23\right)$ had a labeling intensity equal to background levels $\left(3.4 \pm 1.0\right.$ grains $/ 100 \mu \mathrm{m}^{2}$; data not shown; $p>0.05)$, whereas the rest of the striatal population, taken as a whole, had a mean area and grain density of $118 \pm 53$ and $10 \pm 5$ grains $/ 100 \mu \mathrm{m}^{2}$, respectively $(n=527$; data not shown). This last population comprised cells with area ranging between 20 and $299 \mu \mathrm{m}^{2}$ and likely contain glial cells and medium-sized neurons and interneurons, but no difference was found between groups of cells with different area with regards to grain density; grain density levels of this heterogeneous cell population was approximately half of that found in cells of the thalamic reticular nucleus, which were the most labeled neurons in our brain sections $\left(20 \pm 10\right.$ grains $/ 100 \mu \mathrm{m}^{2} ; n=33$; data not shown). There was a statistically significant difference between the group of large striatal neurons $\left(>300 \mu \mathrm{m}^{2}\right)$ and the rest of striatal cells with regard to grain density $(p<0.001$ by KruskalWallis one-way ANOVA on ranks). Among the different striatal cell populations, only large cholinergic neurons have a cell size larger than $300 \mu \mathrm{m}^{2}$. This quantitative results confirmed the observation by Testa et al. (1994) that large striatal cholinergic neurons do not contain mGlu3 mRNA.

\section{DISCUSSION}

One of the primary roles attributed to group II and III mGlu receptors is their ability to reduce presynaptically transmitter release both at glutamatergic and nonglutamatergic synapses (Conn and Pin, 1997; Cartmell and Schoepp, 2000). This effect is usually achieved through an inhibitory action on HVA calcium channels (Stefani et al., 1996; Conn and Pin, 1997). In the present work, we provide evidence for a modulatory role of group II mGlu receptors on striatal cholinergic interneuron excitability. This action on cell excitability might result in the observed decrease in $\mathrm{ACh}$ release. In addition, we demonstrate that the group II mGlu receptor subtype involved is most likely mGlu2.

\section{Modulation of cell excitability by group II mGlu receptors}

Cholinergic interneurons have been shown to play a key role in the basal ganglia circuitry, by influencing the excitability of the 

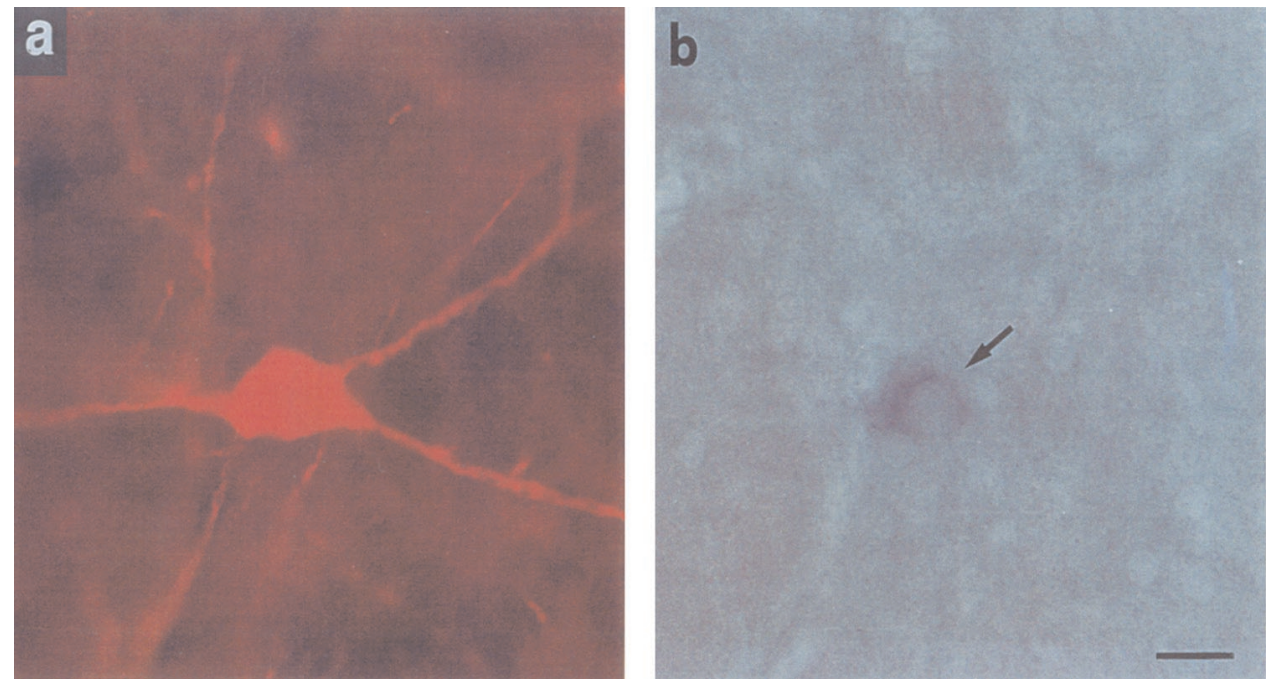

Figure 8. Representative example of ChAT/mGlu2 mRNA-positive neurons in the striatum. On the left $(a)$, a typical ChAT-positive neuron is shown under UV light epifluorescence. On the right $(b)$, the same microscopic field under bright light reveals the mGlu2 in situ hybridization signal (arrow). Scale bar, $20 \mu \mathrm{m}$.

major output neurons of the striatum, the medium spiny projection neurons (Calabresi et al., 2000; Kaneko et al., 2000). Indeed, it is believed that these cells integrate glutamatergic synaptic inputs from thalamus and cortex, with dopaminergic inputs originating in substantia nigra (Graybiel 1990; Kawaguchi, 1993; Kawaguchi et al., 1995). In vivo electrophysiological experiments from primates have identified these cholinergic interneurons as "tonically active neurons" (TANs). They are activated by the presentation of sensory stimuli of behavioral significance or linked to reward (Graybiel et al., 1994; Raz et al., 2001).

A peculiar feature of cholinergic interneurons is represented by a low threshold for firing activity, implying that synaptic inputs may exert a strong influence on spike timing (Wilson et al., 1990). The present results suggest that activation of mGlu2 receptors might effectively modulate synaptic activity through an interaction with P-type calcium channels. Recently, it has been demonstrated that $\mathrm{GABA}_{\mathrm{A}}$ synaptic currents recorded from striatal cholinergic interneurons were reduced by $\sim 95 \%$ by coadministration of N-type and P/Q-type channel blockers (Momiyama and Koga, 2001). Our data on the muscarinic IPSP are in agreement with the study by Momiyama and Koga and demonstrate that the mGlu2-mediated response is occluded by $\omega$-Aga-IVA but also that a further reduction of the synaptic potential is obtained by adding $\mathrm{N}$-type channel blockers. Indeed, the relative contribution of different HVA calcium channels in the modulation of striatal cholinergic interneurons activity is not surprising because both $\mathrm{N}$-type and P-type channels have been shown to mediate the $\mathrm{M}_{2} / \mathrm{M}_{4}$ muscarinic receptor-dependent control of interneuron excitability (Yan and Surmeier, 1996). More recently, release studies performed on brain slices from $\mathrm{M}_{2}$ and $\mathrm{M}_{4}$ receptor single knock-out mice indicated that, in the striatum, the autoinhibitory effect on ACh release is mediated by $\mathrm{M}_{4}$ receptors ( $\mathrm{Z}$ hang et al., 2002).

Although synaptic inputs regulate spike timing (Wilson et al., 1990; Bennett and Wilson, 1998), a key role in the regulation of ongoing spontaneous firing activity has been attributed recently to the intrinsic membrane properties of these cells (Bennett and Wilson, 1999; Bennett et al., 2000). Indeed, calcium entry triggered by firing activity has been shown to shape the action potential waveform and to activate calcium-dependent potassium channels (Bennett et al., 2000). In the present work, we show that mGlu2 receptor agonists shorten calcium-dependent plateau po- tentials, suggesting that they might modulate cell excitability by affecting calcium-dependent potassium conductances.

In line with these data are also our observations that mGlu2 receptor agonists significantly reduce electrically stimulated $\mathrm{ACh}$ release and that this response was mutually occluded by blockade of P-type HVA calcium channels.

Morphological studies provided evidence for either a postsynaptic or a presynaptic localization of the group II mGlu receptor members mGlu 2 and mGlu3. Depending on both the region and the cell type, these receptors subserve a variety of functions. Postsynaptically located group II mGlu receptors may generally modulate cell excitability, whereas presynaptic mGlu2 and mGlu3 serve both as autoreceptors and heteroreceptors, thereby limiting transmitter release (Petralia et al., 1996; Cartmell and Schoepp, 2000). The present work demonstrates that cholinergic interneurons, unequivocally identified by ChAT staining, express mGlu2 receptors. The presence of mGlu 2 receptors on cholinergic neurons, which has been postulated by others on the basis of morphological features, has been here confirmed by means of double labeling. Moreover, we performed a detailed quantitative and statistical analysis on mGlu3 receptor expression in different types of striatal cells, showing that large cells $\left(>300 \mu \mathrm{m}^{2}\right)$ do not contain mGlu3 receptor labeling. Considering that, among the different striatal cell subtypes, only large cholinergic neurons have an area larger than $300 \mu \mathrm{m}^{2}$, we can conclude that striatal cholinergic interneurons express $\mathrm{mGlu} 2$ but not mGlu3 receptor subtypes. In agreement with the present result are previous reports showing that mGlu2 immunostaining was confined to rather large and aspiny cells (Ohishi et al., 1998). Accordingly, the expression of mGlu3 in the striatum was restricted to mediumsized neurons and glial elements (Ohishi et al., 1993; Testa et al., 1994) and terminals of corticostriatal fibers (Tamaru et al., 2001). In our experimental condition, mGlu 2 receptor signal was identified only on neurons and was virtually absent from glial elements.

\section{Lack of effect of group III mGlu receptor agonists}

Both L-AP-4 and L-SOP, selective group III mGlu receptor agonists, failed to significantly alter either the intrinsic membrane properties or the IPSP of the recorded cells. These results were not surprising given the distribution pattern of group III mGlu receptors in the striatum. Ruling out mGlu6, whose expression is 
confined to bipolar cells in the retina, among group III mGlu receptors, a low immunoreactivity for mGlu4 and mGlu8 was detected in the striatum (Saugstad et al., 1997; Bradley et al., 1999). The hybridization signal for mGlu 7 was intense on presynaptic glutamatergic terminals of the corticostriatal pathway and on terminals of GABAergic striatopallidal and striatonigral projection neurons (Kosinski et al., 1999), presumably serving both as autoreceptors and heteroreceptors. Accordingly, cortically evoked EPSPs were reduced by activation of group III mGlu receptors (Pisani et al., 1997; Calabresi et al., 1999). However, cholinergic interneurons and other classes of striatal interneurons showed no labeling for mGlu7 receptors (Kosinski et al., 1999).

\section{Functional implications}

The convergence of $\mathrm{ACh}$ and dopamine in the striatum is central not only to the control of voluntary movement but also to the clinical manifestations of movement disorders such as PD (Kaneko et al., 2000; Raz et al., 2001). Indeed, in vivo recordings from TANs have shown that lesioning the nigrostriatal dopaminergic pathway in primates, such as 1-methyl-4-phenyl-1,2,3,6tetrahydropyridine treatment, lead to an oscillatory electrical behavior, in a frequency range that overlaps the range of the tremor frequencies (Raz et al., 2001). The use of anticholinergic drugs represented one of the earliest therapies to PD, and, on this basis, the hypothesis of an imbalance between dopamine and $\mathrm{ACh}$ in the striatum was postulated. Thus, agents able to modulate the excitability of cholinergic interneurons, and in turn, striatal ACh content could represent an interesting alternative to anticholinergic drugs in the treatment of PD. The present findings suggest a possible synergic pharmacological approach with $\mathrm{D}_{2}$ dopaminergic and mGlu2 receptor agonists, both limiting striatal cholinergic transmission.

\section{REFERENCES}

Aosaki T, Kiuchi K, Kawaguchi Y (1998) Dopamine D1-like receptor activation excites striatal large aspiny neurons in vitro. J Neurosci 18:5180-5190.

Awad H, Hubert GW, Smith Y, Levey AI, Conn JP (2000) Activation of metabotropic glutamate receptor 5 has direct excitatory effects and potentiates NMDA receptor currents in neurons of the subthalamic nucleus. J Neurosci 20:7871-7879.

Barbeau A (1962) The pathogenesis of Parkinson's disease: a new hypothesis. Can Med Assoc J 87:802-807.

Beani L, Bianchi C, Giacomelli A, Tamberi F (1978) Noradrenaline inhibition of acetylcholine release from guinea-pig brain. Eur J Pharmacol 48:179-193.

Bennett BD, Wilson CJ (1998) Synaptic regulation of action potential timing in neostriatal cholinergic interneurons. $J$ Neurosci 18:8539-8549.

Bennett BD, Wilson CJ (1999) Spontaneous activity of neostriatal cholinergic interneurons in vitro. J Neurosci 19:5586-5596.

Bennett BD, Callaway JC, Wilson CJ (2000) Intrinsic membrane properties underlying spontaneous tonic firing in neostriatal cholinergic interneurons. J Neurosci 20:8493-8503.

Bradley SR, Standaert DG, Rhodes KJ, Rees HD, Testa CM, Levey AI, Conn PJ (1999) Immunocytochemical localization of subtype 4a metabotropic glutamate receptors in the rat and mouse basal ganglia. J Comp Neurol 407:33-46.

Calabresi, P. Centonze D, Pisani A, Sancesario G, North RA, Bernardi G (1998) Muscarinic IPSPs in rat striatal cholinergic interneurones. J Physiol (Lond) 510:421-427.

Calabresi P, Centonze D, Pisani A, Bernardi G (1999) Metabotropic glutamate receptors and cell-type specific vulnerability in the striatum: implication for ischemia and Huntington's disease. Exp Neurol 158:97-108.

Calabresi P, Centonze D, Gubellini P, Pisani A, Bernardi G (2000) Acetylcholine-mediated modulation of striatal function. Trends Neurosci $23: 120-126$.

Cartmell J, Schoepp DD (2000) Regulation of neurotransmitter release by metabotropic glutamate receptors. J Neurochem 75:889-907.

Catania MV, Landwehrmeyer GB, Testa CM, Standaert DG, Penney JB, Young AB (1994) Metabotropic glutamate receptor are differentially regulated during development. Neuroscience 61:481-495.
Catania MV, Tölle T, Seeburg PH, Monyer H (1995) Differential expression of AMPA receptor subunits in NOS positive neurons of cortex, striatum and hippocampus. J Neurosci 15:7046-7061.

Catania MV, Bellomo M, Giuffrida R, Giuffrida-Stella AM, Albanese V (1998) AMPA receptor subunit expression in Parvalbumin and Calretinin positive neurons of the rat hippocampus. Eur J Neurosci 10:3479-3490.

Conn JP, Pin JP (1997) Pharmacology and functions of metabotropic glutamate receptors. Annu Rev Pharmacol Toxicol 37:205-237.

Contant C, Umbriaco D, Garcia S, Watkins KC, Descarries L (1996) Ultrastructural characterization of the acetylcholine innervation in adult rat neostriatum. Neuroscience 71:937-947.

Damsma G, Lammerts van Bueren D, Westerink BHC, Horn AS (1987) Determination of acetylcholine and choline in the femtomole range by means of HPLC, a post-column enzyme reactor and electrochemical detection. Chromatographia 24:827-831.

Graybiel AM (1990) Neurotransmitters and neuromodulators in the basal ganglia. Trends Neurosci 13:244-254.

Graybiel AM, Aosaki T, Flaherty AW, Kimura M (1994) The basal ganglia and adaptive motor control. Science 265:1826-1831.

Hornykiewicz O, Kish SJ (1987) Biochemical pathophysiology of Parkinson's disease. Adv Neurol 45:19-34

Kaneko S, Hikida T, Watanabe D, Ichinose H, Nagatsu T, Kreitman RJ, Pastan I, Nakanishi S (2000) Synaptic integration mediated by striatal cholinergic interneurons in basal ganglia function. Science 289:633-637.

Kawaguchi Y (1993) Physiological, morphological and histochemical characterization of three classes of interneurons in rat neostriatum. J Neurosci 13:4908-4923.

Kawaguchi Y, Wilson CJ, Augood SJ, Emson PC (1995) Striatal interneurons: chemical, physiological and morphological characterization. Trends Neurosci 18:527-535.

Kosinski CM, Bradley SR, Conn PJ, Levey AI, Landwehrmeyer GB, Penney Jr JB, Young AB, Standaert DG (1999) Localization of metabotropic glutamate receptor $7 \mathrm{mRNA}$ and $\mathrm{mGluR} 7 \mathrm{a}$ protein in the rat basal ganglia. J Comp Neurol 415:266-284.

Lehmann J, Langer SZ (1983) The striatal cholinergic interneuron: synaptic target of dopaminergic terminals? Neuroscience 10:1105-1120.

Lev-Ram V, Miyakawa H, Lasser-Ross N, Ross WN (1992) Calcium transients in cerebellar Purkinje neurones evoked by intracellular stimulation. J Neurophysiol 68:1167-1177.

Lovinger DM, McCool BA (1995) Metabotropic glutamate receptormediated presynaptic depression at corticostriatal synapses involves mGluR2 or 3. J Neurophysiol 73:1076-1083.

Misgeld U, Calabresi P, Dodt HU (1986) Muscarinic modulation of calcium dependent plateau potentials in rat neostriatal neurons. Pflügers Arch 407:482-487.

Momiyama T, Koga E (2001) Dopamine D2-like receptors selectively block $\mathrm{N}$-type $\mathrm{Ca}^{2+}$ channels to reduce GABA release onto rat striatal cholinergic interneurones. J Physiol (Lond) 533:479-492.

Morari M, Sbrenna S, Marti M, Caliari F, Bianchi C, Beani L (1998) NMDA and non-NMDA ionotropic glutamate receptors modulate striatal acetylcholine release via pre- and postsynaptic mechanisms. J Neurochem 71:2006-2017.

Moroni F, Bianchi C, Tanganelli S, Moneti G, Beani L (1981) The release of gamma-aminobutyric acid, glutamate and acetylcholine from striatal slices: a mass fragmentographic study. J Neurochem 36:1691-1697.

Ohishi H, Shigemoto R, Nakanishi S, Mizuno N (1993) Distribution of the messenger RNA for a metabotropic glutamate receptor (mGluR3), in the rat brain: an in situ hybridization study. J Comp Neurol 335:252-266.

Ohishi H, Neki A, Mizuno N (1998) Distribution of a metabotropic glutamate receptor, mGluR2, in the central nervous system of the rat and mouse: an immunohistochemical study with a monoclonal antibody. Neurosci Res 30:65-82.

Petralia RS, Wang YX, Niedzielski AS, Wenthold RJ (1996) The metabotropic glutamate receptors, mGluR2 and mGluR3, show unique postsynaptic, presynaptic and glial localizations. Neuroscience 71:949-976.

Pisani A, Calabresi P, Centonze D, Bernardi G (1997) Activation of group III metabotropic glutamate receptors depresses glutamatergic transmission at corticostriatal synapses. Neuropharmacology 34: 845-851.

Pisani A, Calabresi P, Centonze D, Marfia GA, Bernardi G (1999) Electrophysiological recordings and calcium measurements in striatal large aspiny interneurons in response to combined $\mathrm{O}_{2} /$ glucose deprivation. J Neurophysiol 81:2508-2516.

Pisani A, Bonsi P, Centonze D, Calabresi P, Bernardi G (2000) Activation of $\mathrm{D}_{2}$-like dopamine receptors reduces synaptic inputs to striatal cholinergic interneurons. J Neurosci 20:RC69(1-6).

Pisani A, Bonsi P, Calabresi P, Centonze D, Bernardi G (2001) Functional coexpression of excitatory mGluR1 and mGluR5 on striatal cholinergic interneurons. Neuropharmacology 40:460-463.

Raz A, Frechter-Mazar V, Feingold A, Abeles M, Vaadia E, Bergman H 
(2001) Activity of pallidal and striatal tonically active neurons is correlated in MPTP-treated monkeys but not in normal monkeys. J Neurosci 21:RC128(1-5).

Saugstad JA, Kinzie MJ, Shinohara MM, Segerson TP, Westbrook GL (1997) Cloning and expression of rat metabotropic glutamate receptor 8 reveals a distinct pharmacological profile. Mol Pharmacol 51:119-125.

Stefani A, Pisani A, Mercuri NB, Calabresi P (1996) The modulation of calcium currents by the activation of mGluRs. Mol Neurobiol 13:81-95.

Tallaksen-Greene SJ, Kaatz KW, Romano C, Albin RL (1998) Localization of mGluR1a-like immunoreactivity and mGluR5-like immunoreactivity in identified populations of striatal neurons. Brain Res 780:210-217.

Tamaru Y, Nomura S, Mizuno N, Shigemoto R (2001) Distribution of metabotropic glutamate receptor mGluR3 in the mouse CNS: differential location relative to pre and postsynaptic sites. Neuroscience 106:481-503.

Testa CM, Standaert DG, Young AB, Penney JB Jr (1994) Metabotropic glutamate receptor mRNA expression in the basal ganglia of the rat. J Neurosci 14:3005-3018.

Testa CM, Standaert DG, Landwehrmeyer GB, Penney Jr JB, Young AB (1995) Differential expression of mGluR5 metabotropic glutamate receptor mRNA by rat striatal neurons. J Comp Neurol 354:241-252.
Testa CM, Friberg IK, Weiss SW, Standaert DG (1998) Immunohistochemical localization of metabotropic glutamate receptors mGluR1a and mGluR2/3 in the rat basal ganglia. J Comp Neurol 390:5-19.

Wheeler DB, Randall A, Tsien RW (1994) Roles of N-type and Q-type $\mathrm{Ca}^{2+}$ channels in supporting hippocampal synaptic transmission. Science 265:107-111.

Wilson CJ, Chang HT, Kitai ST (1990) Firing patterns and synaptic potentials of identified giant aspiny interneurons in the rat neostriatum. J Neurosci 10:508-519.

Yan Z, Surmeier DJ (1996) Muscarinic (m2/m4) receptors reduce Nand P-type $\mathrm{Ca}^{2+}$ currents in rat neostriatal cholinergic interneurons through a fast, membrane-delimited, G-protein pathway. J Neurosci 16:2592-2604.

Yan Z, Song WJ, Surmeier DJ (1997) D2 dopamine receptors reduce $\mathrm{N}$-type $\mathrm{Ca}^{2+}$ currents in rat neostriatal cholinergic interneurons through a membrane-delimited, protein kinase C-insensitive pathway. J Neurophysiol 77:1003-1015.

Zhang W, Basile AS, Gomeza J, Volpicelli LA, Levey AI, Wess J (2002) Characterization of central inhibitory muscarinic autoreceptors by the use of muscarinic acetylcholine receptor knock-out mice. J Neurosci 22:1709-1717. 